\title{
Onychomatricoma: A Rare Nail Tumor with an Unusual Clinical Presentation
}

\author{
Preetha Kamath ${ }^{\mathrm{a}}$ Timothy Wu $\mathrm{W}^{\mathrm{a}}$ Gabriel Villada ${ }^{\mathrm{a}}$ Martin Zaiac ${ }^{\mathrm{a}}$ \\ George Elgart ${ }^{\mathrm{a}}$ Antonella Tosti ${ }^{\mathrm{b}}$ \\ a University of Miami Miller School of Medicine and ${ }^{\mathrm{b}}$ Fredric Brandt Endowed Professor of Dermatology, \\ University of Miami, Miami, FL, USA
}

\section{Established Facts}

- Onychomatricoma is a rare, benign, fibroepithelial tumor of the nail matrix typically occurring in lightcomplexed individuals.

- To date there have been 5 reported cases of giant onychomatricoma, all with a reported history of prior trauma.

\section{Novel Insights}

- Onychomatricoma can also occur in dark-complexed individuals.

- Giant onychomatricoma may present in an individual denying history of trauma to the region after several years of onychomycosis.

\section{Keywords}

Clinical dermatology $\cdot$ Dermatology $\cdot$ Diagnosis $\cdot$ Fungal infection $\cdot$ Medical dermatology $\cdot$ Mycoses $\cdot$ Nail $\cdot$ Nail tumor . Onychomatricoma $\cdot$ Onychomycosis

\begin{abstract}
First described in 1992, onychomatricoma is a rare, benign, fibroepithelial tumor of the nail matrix with few reported cases in the literature. The tumor predominately affects the fingers of Caucasian women during the 5 th decade of life and is typically slow growing and painless. The authors present a unique clinical presentation of a giant onychomatricoma in a darker-skinned 60-year-old South Asian individual who presented with a large dome-shaped nail that was smooth, shiny, and green.

(c) 2017 S. Karger AG, Basel
\end{abstract}

\section{Case Presentation}

A 60-year-old South Asian male presented with a 20-year history of discoloration and thickening of the nail on the left great toe. History revealed that he had a diagnosis of onychomycosis treated with nail avulsion and that the nail had regrown abnormal afterwards. He had been using topical ciclopirox for 2 years without improvement. Apart from cutting the nail and application of ciclopirox solution, the patient denied any other treatment of or trauma to the affected region.

Dermatologic examination revealed a large smooth, shiny, dome-shaped, thickened nail with green, yellow, and brown discoloration as well as longitudinal and transverse overcurvature of the nail plate (Fig. 1). All other toenails were unaffected. A radiograph of the left foot was obtained and revealed no evidence of fracture, bony erosion, or periosteal reaction. Dermoscopy showed an opaque uniformly ivory-colored nail plate. Nail avulsion revealed a nail matrix tumor with projections inside the nail plate (Fig. 2). Surgical excision was performed and a specimen sent for histopathology, with features consistent with onychomatricoma.

\section{KARGER}

(c) 2017 S. Karger AG, Basel

E-Mail karger@karger.com

www.karger.com/sad
Dr. Antonella Tosti

Department of Dermatology and Cutaneous Surgery

University of Miami Miller School of Medicine

1600 NW 10th Ave., Room 2023, Miami, FL 33136 (USA)

E-Mail atosti@med.miami.edu 


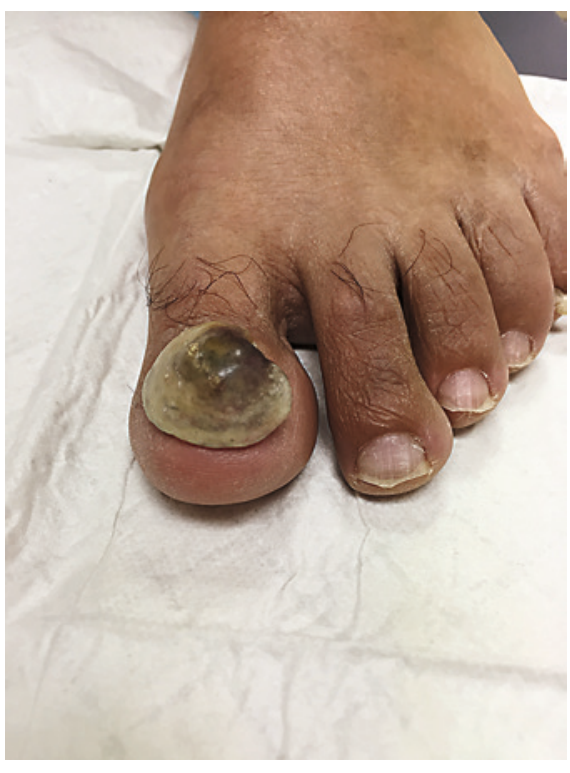

Fig. 1. Large dome-shaped thickened nail, presence of xanthonychia, as well as longitudinal and transverse curvature.

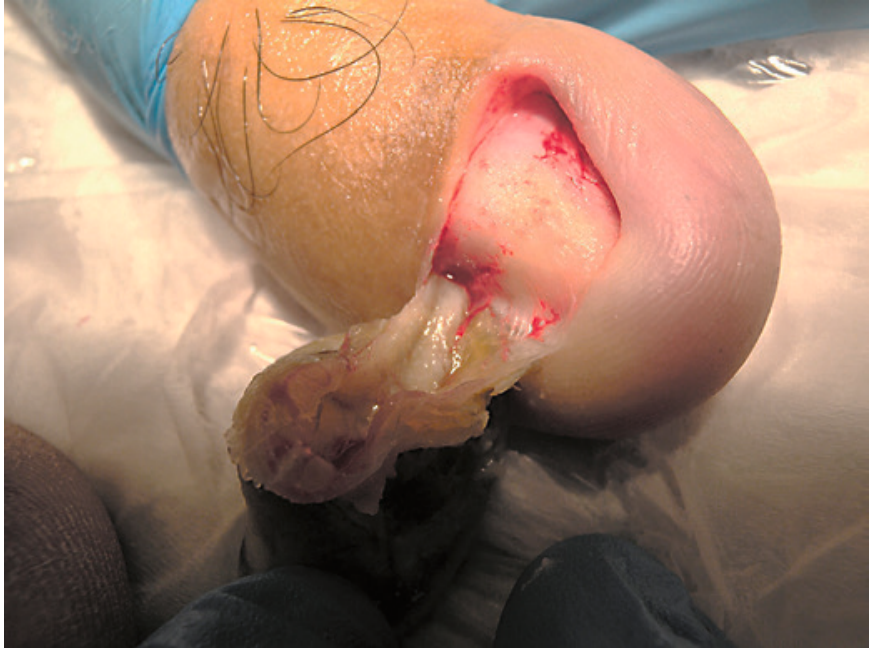

Fig. 2. Intraoperative image revealing the tumor's finger-like filiform projections.

Table 1. Giant onychomatricoma in the literature

\begin{tabular}{|c|c|c|c|c|c|}
\hline Reference & Age, sex, race & Location & Clinical history & Treatment/therapy & Recurrence \\
\hline Prevezas et al. [12] & $\begin{array}{l}73 \text { years, male, } \\
\text { Caucasian }\end{array}$ & $\begin{array}{l}\text { left great } \\
\text { toenail }\end{array}$ & $\begin{array}{l}\text { farmer with over a decade of } \\
\text { minor trauma and nail dystrophy }\end{array}$ & surgical excision & $\begin{array}{l}\text { no recurrence after } \\
1 \text { year of follow-up }\end{array}$ \\
\hline $\begin{array}{l}\text { Fierro-Arias et al. } \\
{[11]}\end{array}$ & $\begin{array}{l}53 \text { years, male, } \\
\text { Mexican }\end{array}$ & $\begin{array}{l}\text { right third } \\
\text { toe }\end{array}$ & $\begin{array}{l}\text { schoolteacher with a } 1 \text {-year } \\
\text { history of posttraumatic lesion }\end{array}$ & surgical excision & $\begin{array}{l}\text { no recurrence after } \\
2 \text { years of follow-up }\end{array}$ \\
\hline Saranya et al. [13] & $\begin{array}{l}80 \text { years, female, } \\
\text { Indian }\end{array}$ & $\begin{array}{l}\text { left great } \\
\text { toenail }\end{array}$ & $\begin{array}{l}\text { painless growth for } 2 \text { years and } \\
\text { history of trauma to the nail by } \\
\text { a blunt object a few months } \\
\text { before onset of the mass }\end{array}$ & surgical excision & $\begin{array}{l}\text { no recurrence after } \\
1 \text { week, then lost to } \\
\text { follow-up }\end{array}$ \\
\hline $\begin{array}{l}\text { Estrada-Chavez et al. } \\
{[10]}\end{array}$ & $\begin{array}{l}\text { case } 1: 59 \text { years, } \\
\text { male, Mexican; } \\
\text { case } 2: 45 \text { years, } \\
\text { female, Mexican }\end{array}$ & $\begin{array}{l}\text { case } 1 \text { : right } \\
\text { thumbnail; } \\
\text { case } 2 \text { : left } \\
\text { thumbnail }\end{array}$ & $\begin{array}{l}\text { case } 1 \text { : } 2 \text {-year history of } \\
\text { painful tumor with previous } \\
\text { trauma; case } 2 \text { : } 3 \text {-year history } \\
\text { of gradual nail dystrophy, } \\
\text { initially treated unsuccessfully } \\
\text { for months with antimycotics, } \\
\text { also with self-induced trauma } \\
\text { to reduce size }\end{array}$ & $\begin{array}{l}\text { case } 1 \text { : avulsion of } \\
\text { the nail plate; case } 2 \text { : } \\
\text { excisional biopsy of } \\
\text { tumor and nail matrix }\end{array}$ & not reported \\
\hline Current publication & $\begin{array}{l}60 \text { years, male, } \\
\text { South Asian }\end{array}$ & $\begin{array}{l}\text { left great } \\
\text { toenail }\end{array}$ & $\begin{array}{l}20 \text {-year history of discoloration } \\
\text { and growth }\end{array}$ & $\begin{array}{l}\text { excisional biopsy of } \\
\text { tumor and nail matrix }\end{array}$ & $\begin{array}{l}\text { no recurrence after } \\
3 \text { months of follow-up }\end{array}$ \\
\hline
\end{tabular}

\section{Discussion}

First described by Baran and Kint in 1992 [1], onychomatricoma is a rare, benign, fibroepithelial tumor of the nail matrix with no more than 80 reported cases in the literature. The tumor predominately affects the fingers of Caucasian women during the 5th decade of life and is typically slow growing and painless [2]. Clinically, onychomatricoma presents with xanthonychia, nail thickening, splinter hemorrhages, longitudinal and transverse overcurvature of the nail plate, and woodworm cavities at the distal margin of the nail plate. Other clinical presentations include longitudinal melanonychia, nail dystrophy, subungual hematoma, as well as nodular and dorsal pte- 
rygium [3]. Avulsion of the nail plate typically reveals a filamentous tumor with multiple tufted, filiform projections arising from the nail matrix projecting onto the nail plate. Histopathological evaluation can confirm the diagnosis, revealing multiple fibroepithelial projections arising from the nail matrix with "glove finger" digitations projecting onto the nail plate [4]. Other modalities that have been shown to aid in the diagnosis of onychomatricomas include nail clipping [5], dermoscopy [6], ultrasound [7], and confocal microscopy [8]. The treatment of choice is nail avulsion with complete surgical excision of the entire matrix proximal to the tumor in order to avoid the risk of recurrence [9]. Recurrence rates are unknown, though few series with long-term follow-up have been reported in the literature.

We report a unique clinical presentation of a giant onychomatricoma in a darker-skinned South Asian individual who presented with a large dome-shaped nail that was smooth, shiny, and green. Most of the reports on onychomatricoma present tumors found only in a portion of the nail plate, demonstrated by a superficial band-like pattern of yellowish discoloration with increased transverse curvature of the nail. To date there have been 5 reported cases of giant onychomatricoma (Table 1), all of them with a history of prior trauma [10-13]. Interestingly, all tumors were found to be located on the great toenail or thumbnail, which are areas that are potentially more susceptible to trauma. While onychomatricoma has been reported more commonly in Caucasians [2], only 1 out of 6 cases (including ours) of giant onychomatricoma was of Caucasian descent.

\section{Statement of Ethics}

The patient's consent for publication was obtained.

\section{Disclosure Statement}

The authors have no conflicts of interest to disclose.

\section{References}

1 Baran R, Kint A: Onychomatrixoma. Filamentous tufted tumour in the matrix of a funnel-shaped nail: a new entity (report of three cases). Br J Dermatol 1992;126:510-515.

2 Di Chiacchio N, Tavares GT, Tosti A, Di Chiacchio NG, Di Santis E, Alvarenga L, Stuhr P, De Farias D: Onychomatricoma: epidemiological and clinical findings in a large series of 30 cases. Br J Dermatol 2015;173: 1305-1307.

3 Tavares GT, Chiacchio NG, Chiacchio ND, Souza MV: Onychomatricoma: a tumor unknown to dermatologists. An Bras Dermatol 2015;90:265-267.

4 Perrin C, Baran R, Pisani A, Ortonne JP, Michiels JF: The onychomatricoma: additional histologic criteria and immunohistochemical study. Am J Dermatopathol 2002;24:199203.
5 Miteva M, de Farias DC, Zaiac M, Romanelli $\mathrm{P}$, Tosti A: Nail clipping diagnosis of onychomatricoma. Arch Dermatol 2011;147:11171118 .

6 Lee DY, Lee JH: Use of dermoscopy to identify nail plate cavities as a clinical diagnostic clue for onychomatricoma. Int J Dermatol 2016;55:e108-e110.

7 Soto R, Wortsman X, Corredoira Y: Onychomatricoma: clinical and sonographic findings. Arch Dermatol 2009;145:1461-1462.

8 Sanchez M, Hu S, Miteva M, Tosti A: Onychomatricoma has channel-like structures on in vivo reflectance confocal microscopy. J Eur Acad Dermatol Venereol 2014;28:1560-1562.

9 Van Holder C, Dumontier C, Abimelec P: Onychomatricoma. J Hand Surg Br 1999;24: 120-121.
10 Estrada-Chavez G, Vega-Memije ME, Toussaint-Caire S, Rangel L, Dominguez-Cherit J: Giant onychomatricoma: report of two cases with rare clinical presentation. Int J Dermatol 2007;46:634-636.

11 Fierro-Arias L, Corrales-Rosas B, MercadilloPérez P, Medina-Castillo D, Peniche-Castellanos A: Giant onychomatricoma in third toe: exceptional condition with surgical resolution. J Eur Acad Dermatol Venereol 2016;30: 525-527.

12 Prevezas C, Triantafyllopoulou I, Belyayeva $\mathrm{H}$, Sgouros D, Konstantoudakis S, Panayiotides I, Rigopoulos D: Giant onychomatricoma of the great toenail: case report and review focusing on less common variants. Skin Appendage Disord 2016;1:202-208.

13 Saranya M, Saritha M, Karthikeyan K: Ram's horn nail - giant onychomatricoma treated by complete surgical excision - a rare case report. Indian J Dermatol 2015;60:523. 